S sciendo $\frac{\text { ECONOMIC THEMES (2018) 56(2): 139-160 }}{\text { DOI 10.2478/ethemes-2018-0009 }}$

\title{
PREFERABLE DIRECTIONS IN REFORM OF THE INTERNATIONAL TRADING SYSTEM FROM THE STANDPOINT OF DEVELOPMENT NEEDS OF THE SMALL COUNTRIES IN EASTERN EUROPE
}

\author{
Marko Đogo \\ University of East Sarajevo, Faculty of Economics, Bosnia and Herzegovina \\ $\triangle$ markodjogo@yahoo.com \\ Vesna Prorok \\ University of East Sarajevo, Faculty of Economics, Bosnia and Herzegovina \\ $\square$ vesna.prorok@gmail.com
}

UDC

339.5

Review

paper

Received:

12.02 .2018

Accepted:

28.05.2018
Abstract: The economic openness and reindustrialization. Can these two occurrences exist at the same time? The empirical experience of the East European countries tells us that they cannot. Trade liberalization in the transition countries implemented during the 1990s led to the process of deindustrialization which continued also during the 2000s. The goal of this paper is to present the possible directions for reform of the international trade system which would enable reindustrialization of the small countries in East Europe with simultaneous preservation of the achieved level of trade liberalization. Admittedly, we are separated from the win-win situation by the conviction that this is only possible if the compensation principle is applied on the global trade, according to which the winners in the global trade (developed countries with trade surplus), should compensate to the losers (small insufficiently developed countries) a part of their losses with mandatory support to programs of reindustrialization based on exports, for which the funds are chronically lacking. An alternative is reindustrialization based on import substitution i.e. strengthening of the protectionism, where all benefits of the free trade could vanish so in the end everybody would be in loss.

Keywords: trade barriers, gains from trade, small countries

JEL classification: F13, F41 
Primary trend within international trade system since WWII up to date, at least from the position of developed countries, is liberalization. Prevailing opinion in developed countries until recently was that is about the irreversible process (TINA ${ }^{1}$, "the end of a history") which comes to an end by general global liberalization of flows of goods, capital and people. However, we witness to reexamination of this model and this just by citizens and politicians of developed countries. Recent researches, such as books Global inequality- new approach in globalization era, (Milanović: 2016), and Rewriting the rules of American Economy: An agenda for growth and shared prosperity (Stiglitz: 2015), points to suffering the poor social classes are going through in developed countries. In addition, globalization process brought a suffering to great number of people of East Europe. Therefore, if possible change of rules is discussed than their needs should be taken into consideration.

The most often mentioned solution for economic issues of small East European countries is reindustrialization. Here, the notion of industrialization itself is disputable. As suggested by Piketty (2015) all developed countries of today had passed through the deindustrialization process during last 60 years. However, any of government of developed countries does not base future developed on reindustrialization. Does it mean that all governments of the East European countries are wrong?

No. There is one essential difference between deindustrialization in developed countries and countries in transition. Transition countries passed through deindustrialization on the level of income which, in the second half of the 1990s, was between 620 \$ (Albania) and 6,500 \$ (Czech Republic) per capita. According to the general position derived from experience of developed countries, expressed, for example, in Global Competitiveness Report, that deindustrialization is being reached at the income from 9,000 to 17,000 \$, it seems that countries of East Europe carried out the industrialization too early. In other words, they carried out trade liberalization too early or that they are still at the BDP level which would require prevailing share of industry in the BDP, which, obviously, is not the case. However, trade liberalization is something that has such positive effects attributed to it by theory and practice, especially regarding small countries.

\section{Introduction}

"If anyone has doubts about openness, try isolation. Cambodia did, and we sure do not want to go back." (IMF Paper, 2005: 13). This statement of the Cambodian Trade minister, Mr. Sok Siphana, well summarises fears from strengthening of protectionism.

\footnotetext{
${ }^{1}$ Neologism of Margaret Thatcher There is no Alternative

${ }^{2}$ Famous book of Francis Fukuyama, 1992, The End of History and the Last Man
} 
However, in a world today the autarchy is not a real threat. Number of countries which exist in some form of autarchy is minor and, for sure, these are not countries which would motivate others to follow the same direction. In addition, openness has not always provided great results in spite of developed theory in favor of free trade. Numerous papers suggest that the deindustrialization process achieved by East European countries had negative economic-social consequences. Some authors see this process as a threat to sustainable long term development of these countries. Indeed, due to objectivity of research here is necessary to emphasise the specificity of economic situation in transition countries before the liberalization. Specifically, before liberalization, at the beginning of the 1990s, a trade exchange in the most communist countries had developed within SEV imposed by the USSR. Exchange was under political patronage of the USSR so the most East European countries had a trade deficit with the USSR and a significant part of trade was in form of barter arrangements, the model used by the USSR in trade with developed countries too (Vuic, 2010). Therefore, an objective question could be raised if the industrialization of the East Europe countries after WWII was real at all, or it was the case of imposedideological industrialization where the input would be, with fall of communism, withdrawn in other industries even without trade liberalization.

In any way, the rate and magnitude of change in economic structure of East European countries during the1990s could be compared only with industrialization of the USSR in the 1920s and the 1930s, just as it does Bhagwati referring to Keynes' paper from 1933. However, there is one substantial difference. Specifically, at the time Lenin tried to transition the USSR from semi-feudal-agrarian society, he was aware of casualties to be sustained in order to achieve such change, but he was ideologically prepared to accept such sacrifice. This could be seen from the following quote: ,Weare fifty or a hundred years behind the advanced countries. We must make good this distance in ten years. Either we do it, or we shall be crushed." (Vietor, 2010: 184).However, in the late 1980s, population of East European countries did not expect sacrifices in transformation from closed to open economies, but prosperity that had been promised. Change from uncompetitive closed industrialized central-planned economies into modern, market, opened capitalist post-industrial economies had not been easy. This change, however, did not resulted in creation of gulags but caused resettlement of tenths of millions of mostly young people of East European countries (Đogo, 2009) which is not a tragedy for those societies only, but it directly affected to structure of labour, i.e. it negatively reflected on a growth of labour productivity and ipso facto to slowdown of economic growth.

As we already stated, the most governments see reindustrialization as an instrument for the population in East European to stay in their countries and economic growth, and they are aware that their population cannot compare to population of developed countries in modern industries, today called economy of knowledge or development based on innovations. 
However, the reindustrialization is expensive. No matter who is in question, domestic or foreign investors, investments into new industrial capacities are not without significant subventions and provision of other conditions; from modern infrastructure (highways, railroad transportation, airports and ports), to educated and sufficiently mass and cheap labour. East European countries which mostly need foreign and domestic investments are, as a rule, the same ones with the biggest trade and budget deficit so their ability to implement reindustrialization is the lowest. Therefore, social pressure is rising to limit the free trade and to turn to industrialization through substitution of import. The answer which comes from international multilateral institution can be brought to the thesis that trade liberalization is award by itself and support of these institutions is not compensation for participation in international trade, but the way showing how to achieve macroeconomic balance. The goal of this paper is just to check if the openness is award by itself and if industrialization is necessary for small countries of East Europe at all if openness is sufficient incentive for development.

The authors' thesis is: Benefits from trade liberalization cease after a certain level of itis reached, while the sector structure of GDP cannot be neglected. Countries with medium income level with larger share of industry in generating of $G D P$, in conditions of high openness of the country, are countries with potentially more important and more sustainable rate of midterm economic growth.

\section{Literature Review}

In XXI century, the primary communication media, even in scientific community, is internet, i.e. various portals, websites, blogs and similar. Therefore, it is not a surprise that we have come to idea to write this paper after reading the articles of the group of Nobel's prizewinners for economy (Spens, Stiglitz, Deaton, Phelps) published within the Project Syndicate ${ }^{3}$ website. These articles have titles: What have neo-liberals lied to us (Stiglitz: 2016), Flaws of the Robin Hood principle (Deaton: 2016), Good economy for good life (Phelps: 2016) and Robots will produce sneakers (Spens: 2016).

However, group of papers, books, textbooks and other which refer to issue of connection of the country openness or globalization with economic development rates is so broad and we are going to mention just some of those which directly influenced to content of this paper.

We shall try here to refer to the parts in these works in order to provide a context of their use.

\footnotetext{
${ }^{3}$ According to The Guardian: "Project Syndicate produces and delivers original commentaries by prominent economists, political leaders, scholars, business leaders, and civic activists to a global audience, including nearly 500 media outlets in more than 150 countries", https://www.theguardian.com/business/series/project-syndicate-economists. (date of access: 15.6.2017).
} 
At the beginning, there are two influential books that have already been mentioned: Globalization and Its Discontents, (Stiglitz: 2002) and In Defense of Globalization, (Bhagwatti: 2004). In first case, Stiglitz (2002) directly points to negative effects which globalization, or, in this case, transition, had on lives of millions of people in East Europe. Considering that the subject of our observation are the small countries of East Europe and trade liberalization which occurred through transition and globalization, this source was inevitable for us although this book had the first issue in far back in 2001.

Opposite to Stiglitz, Bhagwati can be considered as an apologist of globalization who tries to give it a human face. Although the globalization for Bhagwati (2004) is a way for millions of people to get out from poverty, it is interesting that even him, as prominent liberal, stands for optimal rate of trade liberalization, which can be observed as one of chapters in his book has a title: Managing Transition: Optimal, Not Maximal, Speed (pg. 253). In this chapter Bhagwati finds that the fathers of economic science and macro economy: Adam Smith and Keynes advocated for gradual trade liberalization, or, gradual reforms in economy. Bhagwati (2005) also admit mistakes made during early stages of transition in Russia what we can see from next quotation: "We need to ensure that we do not repeat the mistakes made by the reformers in Russia, where shock therapy was tried and failed."(p. 19). What is also important for this paper is Bhagwati's (2005) stance in favor of financial support to countries in development:

I have long argued that the development countries often lack adjustment assistance programs of the kind that the developed countries, which have liberalized trade far more (contrary to Oxfam's ill-informed talk about "double standards" in trade), have evolved over time. But how can the poor countries finance such programs? Evidently, aid agencies such as the World Bank can be mobilized to provide such funds to support trade liberalization (p.19).

After these two, would like to indicate that one of the most significant economists of today, Paul Krugman, has been dealing with this topic. The authors would like to emphasise two observations from his large scale opus, relevant for this paper. Krugman (1994) delivered an opinion at the beginning of the 1990s in favor to trade liberalization which could be observed in quote that trade liberalization is „prettygood, if not perfect",and that,,any effort to deviate from it will probably end up doing more harm than good" (pg. 364). However, Krugman's position considering industrialization is relevant for our paper as well. In one of the most famous today's textbooks of international economy (Krugman \& Obstfild: 2009) mentioned here due to many empirical examples making it relevant, Krugman declares himself in favor of industrialization and import openness by giving as an example the new industrial countries (NIC) which, thanks to industrialization based on export during the 1970s, got out from poverty and repressive political systems. 
Since the authors are mentioning textbooks which in their contents deal with this subject, they are sufficiently good to transcendent the most of books and they are so influential that it would be unacceptable not to mention them. Among those books is a textbook: International Economy by Dominick Salvatore. Advantages of free trade are so clearly explained in this textbook that is almost impossible to reject them. Salvatore indicates economy of volume, efficient utilization of resources which does not allow autarchy, even to very large and developed countries, and indicates endogenous theory of economic development and growth initially developed by Romer (1994) and Lucas (1988) which argues that there are at least six channels through which a free trade positively affects the economic development and growth, including also the positive influence on avoidance of the prices distortion, incites faster introduction of new products and services, supports investments into research and development (R\&D), encourages production of intermediate inputs which, according to Miroudot (2009) today make 56\% of trade with goods and approximately $70 \%$ of trade with services.

It is particularly interesting that on the basis of these theories, but also empirical researches of World bank based on studying three group of countries (rich countries, countries in development engaged in globalization, countries in development not engaged in globalization) in period from the 1960s to the 1990s, Salvatore (2009) comes to conclusion that countries in development engaged in globalization were countries with highest rate. However, those who came to different conclusion are not so rare. For example, in the book Bad Samaritans Chang (2016), studying countries of Latin America and Africa, came to conclusion that the GDP of Latin America grew by rate of approximately $3.1 \%$ on annual basis in the 1960 s and the 1970 s, where these countries used in a great degree protective measures and it fell down to approximately $1.7 \%$ in the $1990 \mathrm{~s}$, after these countries liberalized their trade. This comparison is even more unfavourable for Africa. According to Chang, the rate of real economic growth of Africa falls down from approximately 1-2\% during the 1960s and the 1970s to negative rate during the 1990 s.

After the book Why Nations Fail by Acemoglu and Robinson (2012), it is very difficult to deal with the development issue and not to mention importance of a nature of economic and political institutions in such development. Talking about the problem of transition countries our presumption is that these problems would have not occur due to nonexistence of preconditions, or, concretely, institutions in transition countries which would enable market economy to function immediately due to which the quick privatization, liberalization and restitution brought the collapse of existing economic structure, but without power to construct some new economy which would absorb released resources. While the authors talk about lack of institutions the authors do not see such deficiency in obvious disruption of rule of law principle and democracy, which should be a precondition for healthy economic development, but also in repercussions which occurred due to nonexistence of any form of business planning. 
In book How countries compete,Vietor (2010) on the example of Russia, directly talks about the collapse of economy which occurred because the institution which would enable a shock therapy to lead to functioning of economy on market principles were not built. Following quote speaks about it:” „To reform before rebuilding itsinstitutions proved to be a costly mistake " (Vietor, 2010: 203). Indeed, Vietor (2010) connects directly the economic recovery of Russia with arrival of more authoritative power which has returned to certain forms of government, and accordingly, to planning of economic development: „We see in the Russia story the importance of governmentof good government - in building a nation, directing strategy and managing growth" (pg. 203). Connections between Vietor and Acemogly and Robinson lays in Vietor's observation that in Russia in the first ten years of transition the construction of extractive economic institutions was done (such as infamous arrangements „loans for ownership over public enterprises") by which, in fact, the property which passed into hands of Russian elite, called oligarchs, was robbed to the detriment of the rest of society, and in all this were elements of a real robbery rendered possible by the state, and even democracy itself was disturbed in a way that oligarchs took significant political power as well (Vietor, 2010).

In terms of researches of transition, or globalization, connection with development of Balkan countries, the authors would like to emphasise three papers. As citizens of Bosnia and Herzegovina, the authors would start from the paper of professor Stojanov (2012) with rather dramatic title: Dark Age of macroeconomics: The case study of transition in Bosnia and Herzegovina. In this paper professor Stojanov (2012) criticises IMF, World Bank and USAID for which he claims that they conducted transition process in $\mathrm{BH}$, and catastrophic results thereof are the consequence of later recommendation of Washington consensus to which professor Stojanov attributes disregarding the importance of the foreign supply in the economy.

Nenad Pandurevic (2015) came to the same conclusion in his doctoral thesis „Free Trade and Foreign Policy in Function of Economic Development and European Integration of Bosnia and Herzegovina ", where referring to reports of the World Bankhe claims that the World Bank insisted on quick liberalization of the BH foreign trade and even before revitalization of economy and illustrated it by quote from one of the World Bank's reports:

Bosnia and Herzegovina should start with trade reforms as soon as possible. Main steps in liberalization -decrease of customs duties and elimination of noncustoms barriers - should be taken now, before recovery and not to be implemented gradually with economic revitalization... Once when companies get the protection it will be extremely difficult to remove it(pg. 122).

Third paper is Industrialization in response to question-is recovery of countries in transition possible and how, Anđelko Lojpur (2016), where he practically draws a map of East European countries which had achieved a net benefit from transition and those with net loss and recommends reindustrialization as a path for them to get out from the current situation. 
At the end, the authors cannot avoid to mention two books which criticize the globalization from very different position. Those are already mentioned Global inequality - new approach for the age of globalization, Branko Milanovic (2016), who, on the basis of data analysis from 1998 to 2008, presents a conclusion according to which $1 \%$ of the richest citizens in developed countries and newly established middle class in successful development countries, among which the most important is China, gained benefits from the globalization. Stiglitz, with whom the authors started and finalise the presentation of relevant literature, came to similar conclusion. In the book New Rules of American Economy he advocates against agreements TTIP and TPP.

\section{Empirical analysis}

The objective of the analysis was to determine whether and to what extent, on the one hand, the degree of openness of the economies in transition, and on the other hand, industrialization rate, contributes to the growth of GPD both in the long-term and short-term. The analysis was performed with the use of annual panel data sets of the degree of openness of the economy, industrialization rate and the growth rate of GDP for the 15 transition countries of Eastern and South-Eastern Europe in the period from 2000 to 2014. Data were collected from World Bank sources that are processed in accordance with the purpose of the research.

For the purpose of co-integration analysis the authors will primarily verify the level of stationarity of panel time series of observed variables by applying panel unit root tests of the first generation, and then, depending on the results of panel unit root tests, the authors will access the appropriate methodology to establish the existence of co-integration relationship between on the one hand, the degree of openness of the economy and gross domestic product growth rate, and on the other hand, industrialization rate and gross domestic product growth rate.

\subsection{Panel unit root tests}

The earliest tests, in financial literature known as the first generation of tests of the existence of a unit root in panel date series were based on the assumption of crosssectional independency. Despite the fact that such assumption is often unrealistic, the authors of the first generation of panel unit root tests in most cases their researches oriented toward the analysis of autoregressive processes with a set of appropriate restrictions on observation units or variables in panel.

If we compare time series and panel unit root tests we notice that the main difference occurs in terms of the heterogeneity of the model parameters. Given that the time series analysis is performed on the data of one unit of observation in a certain period of time, it is logical that it does not question the existence of homogeneity of the model parameters. However, when it comes to panel data that include a larger 
number of observation units, the question arises whether, when testing the existence of a unit root, one could use the same autoregressive model for all observation units, or it is required for each unit of observation to form a different autoregressive model in order to describe the dynamics of the dependent variable. In accordance with this, the model restrictions for the first generation tests mainly referred to whether the autocorrelation coefficients are identical or different for each unit of observation. Into the first group of tests which imply homogeneity of autocorrelation coefficients belong Lavin, Lin and Chu (LLC), Breitung, Harris-Tzavalis (TH) and Hadri test, while the second group of tests based on the heterogeneity of autocorrelation coefficients include tests such as Im, Pesaran and Shin (IPS), and Maddala Wu and Choi test. One of the most commonly used tests is the first generation LLC (Levin, Lin and Chu) test which implies a homogeneous structure among cross-sections, but also allows heterogeneity of individual deterministic components (constant and trend). Testing the existence of a unit root is based on a common approach to the application of the Augmented Dickey-Fuller test that assesses the model of the following form:

$$
\Delta y_{i t}=\alpha_{i}+\delta_{i} t+\rho^{*} y_{i, t-1}+\sum_{l=1}^{p_{i}} \theta_{i l} \Delta y_{i, l-1}+\varepsilon_{i t}
$$

where $\rho^{*}=\rho-1$, assuming that $\rho=\rho_{i}$, by which the assumption of a homogeneous structure among cross-sections is fulfilled.

The null hypothesis of LLC test implies the existence of a unit root for all units of observation, while alternative refers to their stationarity. So, the null and alternative hypotheses can be expressed as follows:

$$
\begin{aligned}
& H_{0}: \rho^{*}=0 \\
& H_{1}: \rho^{*}<0
\end{aligned}
$$

In their paper, Levin, Lin and Chu (2002) applying Monte Carlo simulation techniques proved that LLC test provides the best results on samples that include between 10 and 250 observation units, where each unit is represened by time series of a length from 25 to 250 time instances.

Although the LLC test is often used in different studies, the authors need to point out that its main disadvantage refers to restrictive assumption that the time series of absolutely all observation units have or do not have a unit root, and to the assumption of homegeneity of autocorrelation coefficients.

A similar, but simpler test was proposed by Harris and Tzavalis (1999). Their test, unlike the LLC test, was based on the assumption of variance homogeneity and was intended to provide efficient results for obsevation units that have a relatively small number of time series intsances. 
One of the tests from this group is the Hadri test as well, whose null hypothesis is defined opposite the aformentioned tests. In other words, the null hypothesis assumes that each individual time series is stationary, as opposed to the alternative hypothesis that each time series has a unit root. Hadri test is similar to the KPSS unit root test in time series analysis (Kwiatkowski, Phillips, Schmidt and Shin (1992)). It is based on the Lagrange multiplier (LM)test of the residuals obtained on the basis of estimated regression model of dependent variable on constant, or on constant and trend, using ordinary least square estimation method (OLS). Regression models used for Hadri test are of the following form:

1) Model of random walk (that includes only constant)

$$
y_{i t}=\alpha_{i t}+\varepsilon_{i t}, \text { and }
$$

2) Model that include constant and trend

$$
y_{i t}=\alpha_{i t}+\beta_{i} t+\varepsilon_{i t}, \quad i=1, \ldots, n, t=1, \ldots, T
$$

where $\alpha_{i t}=\alpha_{i, t-1}+u_{i t}$ is random walk. $\varepsilon_{i t} \sim \operatorname{IIN}\left(0, \sigma_{\varepsilon}^{2}\right)$ and $u_{i t} \sim \operatorname{IIN}\left(0, \sigma_{u}^{2}\right)$ are mutually independent.

Hadri test statistics is given by:

$$
L M=\frac{1}{N T^{2}} \sum_{i=1}^{N} \sum_{t=1}^{T} \frac{S_{i t}^{2}}{\hat{\sigma}_{e i}^{2}}
$$

where $S_{i t}=\sum_{j=1}^{t} \hat{e}_{i j}$ it the partial sum process. Under the null, $\hat{e}_{i j}$ are OLS residuals from regression models and $\hat{\sigma}_{e i}^{2}$ is an estimator of the variance of $e_{i j}$, where $\hat{\sigma}_{e i}^{2}=\frac{1}{T} \sum_{t=1}^{T} \hat{e}_{i t}^{2}$. Based on LM statistics, we get z-statistics which under certain conditions tends to standardized normal distribution. According to some researches, Hadri test provides good results in the case when panel series has a moderate number of observation units $N$, where each unit has a relatively large number of time series data.

The first who tried to overcome the aforementioned drawbacks of the first generation of tests which imply homogeneity of autocorrelation coefficients, and also to increase the power of panel unit root tests were Im, Pesaran and Shin (2003). They proposed and formed the test (IPS test) based on the average value of individual unit root statistics. The initial model of IPS test contrains heterogeneous autocorrelation coefficients, meaning that coefficients of lagged dependent variable are not the same among cross-sections. IPS $\bar{t}$-stastistics is obtained as the average 
value of $t$-statistics of Augmented Dickey-Fuller test calculated for each unit of observation induvidually:

$$
\bar{t}=\frac{1}{N} \sum_{i=1}^{N} t_{\rho_{i}}
$$

The null and alternative hypothesis of IPS test are defined as follows:

$$
\begin{gathered}
H_{0}: \rho_{i}<1 \text { or } \rho_{i}^{*}=0 \\
H_{1}: \rho_{i}<1 \quad \text { or } \rho_{i}^{*}<0 \quad \text { for } i=1,2, \ldots, N_{1} ; \\
\rho_{i}=1 \text { or } \rho_{i}^{*}=0 \quad \text { for } i=N_{1}+1, \ldots, N .
\end{gathered}
$$

The null hypothesis of IPS test assumes the existence of a unit root in time series of all observation units, as opposed to alternative that assumes that at least one time series of all observation units does not contain a unit root, meaning that it is stationary at the level of data for which the testing is done.

Applying Monte Carlo simulation techniques, the authors of IPS test proved that the test provides satisfactory results even in the case of small samples, ie. the small number of both obervation units and time intervals. Although IPS test provides better results compared to the LCC test, such results with restrictions concerning its use exclusively in the balanced panel data, the use of the same number of lags in individual regressions in the implementation of Augmented Dickey-Fuller test can, however, in certain situations lead a user to wrong conclusions.

The tests that provided further improvements in respect of testing of a unit root in panel data are tests of Fisher type, which are known in the literature as combined unit root tests. There are two of such tests proposed by Madalla and $\mathrm{Wu}$ (1999) and Choi (2001) and their adventage lies primarily in the fact that they can be used even when available data is of unequal time-series length over cross-sections and can enable as well different values of stochastic and nonstochastic components for each individual test. These tests are based on the use of nonparametric tests to ensure the removal of autocorrelation, but without introducing additional lags in the model. Maddala and $\mathrm{Wu}$ test requires predetermined number of lags in the model, while Choi test in addition to specification of exogenous variables (constant or constand and trend) requires the specification of method for th evaluation of spectral analysis (Gligoric, 2015).

With proposed tests, Madalla and Wu (1999) and Choi (2001) sought to overcome the deficiency of existing tests in view of the request that each observation unit must contain the same number of time instances. It is achieved by defining the tests based on combination of $p$-values of indepedent time series tests for each observation unit individually. 
Madalla and $\mathrm{Wu}$ proposed the application of the inverse $\chi^{2}$ test of the form: $P=-2 \sum_{i=1}^{N} \ln \left(p_{i}\right)$, while Chio proved that the best properties has the inverse test of normal distribution: $Z=\frac{1}{\sqrt{N}} \sum_{i=1}^{N} \Phi^{-1}\left(p_{i}\right)$, in which $\Phi$ represents the standardized cumulative normal distribution function (Glavaški, 2016).

The null and altenative hypothesis of two previously mentioned tests are defined in the same way as hypothesis of IPS test.

Table 3.1. The results of unit root tests for a series of panel data at the level of the variables : GDP growth, TGDP and IND

\begin{tabular}{|c|c|c|c|c|c|c|}
\hline & \multicolumn{2}{|c|}{ GDP growth (annual } & \multicolumn{2}{|c|}{ 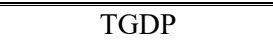 } & \multicolumn{2}{|c|}{ IND ( $\%$ of GDP) } \\
\hline & Statistic & p-value & Statistic & $\mathrm{p}$-value & Statistic & p-value \\
\hline LLC -intercept & - & $0.0000^{* *}$ & -3.12404 & $0.0009^{* *}$ & -3.68637 & $0.0001^{* *}$ \\
\hline $\begin{array}{l}\text { LLC - intercept and } \\
\text { trend }\end{array}$ & $\begin{array}{c}- \\
9.02166\end{array}$ & $0.0000^{* *}$ & -4.14673 & $0.0000^{* *}$ & -2.13242 & $0.0165^{* *}$ \\
\hline LLC - none & - & $0.0000^{* *}$ & 2.45689 & 0.9938 & -1.63121 & 0.0514 \\
\hline $\begin{array}{l}\text { Breitung t-stat - } \\
\text { intercept and trend }\end{array}$ & $\begin{array}{c}- \\
7.08074\end{array}$ & $0.0000^{* *}$ & -1.83926 & $0.0329^{* *}$ & 0.49737 & 0.6905 \\
\hline IPS - intercept & - & $0.0000^{* *}$ & -0.62195 & 0.2670 & -1.63967 & 0.0505 \\
\hline $\begin{array}{l}\text { IPS - intercept and } \\
\text { trend }\end{array}$ & $\begin{array}{c}- \\
3.44213\end{array}$ & $0.0003^{* *}$ & -1.83015 & 0.3206 & 0.90355 & 0.8169 \\
\hline $\begin{array}{l}\text { Fisher ADF - } \\
\text { intercept (Maddala i }\end{array}$ & 62.7219 & $0.0004^{* *}$ & 34.0184 & 0.2801 & 40.6049 & 0.0937 \\
\hline $\begin{array}{l}\text { Fisher ADF - } \\
\text { intercept and trend } \\
\text { (Maddala i Wu) }\end{array}$ & 56.5866 & $0.0023^{* *}$ & 46.5920 & $0.0273^{* *}$ & 23.2510 & 0.8048 \\
\hline $\begin{array}{l}\text { Fisher ADF - none } \\
\text { (Maddala i Wu) }\end{array}$ & 68.6682 & $0.0001^{* *}$ & 6.98428 & 1.0000 & 25.3139 & 0.7096 \\
\hline $\begin{array}{l}\text { Fisher PP - intercept } \\
\text { (Choi) }\end{array}$ & 55.8712 & $0.0028^{* *}$ & 27.3332 & 0.6057 & 43.5820 & 0.0520 \\
\hline $\begin{array}{l}\text { Fisher PP - intercept } \\
\text { and trend (Choi) }\end{array}$ & 49.0309 & $0.0156^{* *}$ & 32.7881 & 0.3318 & 18.2283 & 0.9547 \\
\hline $\begin{array}{l}\text { Fisher PP - none } \\
\text { (Choi) }\end{array}$ & 74.6876 & $0.0000^{* *}$ & 7.65207 & 1.0000 & 42.5470 & 0.0642 \\
\hline Hadri - intercept & 3.75219 & $0.0001^{* *}$ & 6.73173 & $0.0000^{* *}$ & 5.90699 & $0.0000^{* *}$ \\
\hline $\begin{array}{l}\text { Hadri - intercept } \\
\text { and trend }\end{array}$ & 4.78329 & $0.0000^{* *}$ & 4.67342 & $0.0000^{* *}$ & 7.04760 & $0.0000^{* *}$ \\
\hline
\end{tabular}

Source: Author's calculations

** Denotes significance at the level of 5\%

Given the fact that in the context of our analysis the authors dispose with annual data on the degree of openness of the economy (TGDP), industrialization rates (IND) and rates of GDP growth (GDP growth) in the period from 2000 to 2014, and taking into consideration the fact that the power of the tests can be violated in the case of 
shorter time series, the authors decided to make decision on the existence of a unit root using a number of different tests. The results of tests applied to data at the level of the degree of openness of the economy, industrialization rate and gross domestic product growth rate are shown in Table 3.1, where for appropriate tests the authors used as well the results of tests for models that included contstant or constant and trend. In determining the optimal number of lags of autoregressive model in a series of panel data at the level, as well as for data at the first difference, the authors used Schwarz's criteria. Also, for appropriate tests the authors used both the Newey-West bandwith selection method and the Bartlett kernel spectral estimation method.

As it can be seen from Table 3.1, the results of most unit root tests (all tests except Hadri test) for gross domestic product growth rate suggest that the hypothesis of the existence of a unit root can be rejected for data at the level, what means that one can accept the alternative hypothesis of stationarity of a series of panel data. On the other hand, the results of tests for the degree of openness of the economy and industrialization rate for data at the level are not uniform. Most of the tests showed that the null hypothesis of the existence of a unit root for data at the level cannot be rejected for the degree of openness of the economy, neither for the industrialization rate. For this reason, the authors will approach testing for stationarity of a series of panel data at the first difference for both the degree of openness of the economy and industrialization rate. Results of panel unit root tests for data at the first difference are shown in Table 3.2.

Table 3.2. The results of unit root tests for a series of panel data at the first difference of the variables: TGDP and IND

\begin{tabular}{||l|c|c|c|c||}
\hline \multirow{2}{*}{} & \multicolumn{2}{|c|}{$\Delta \mathrm{TGDP}$} & \multicolumn{2}{c|}{$\Delta \mathrm{IND}$} \\
\cline { 2 - 5 } & Statistic & $\mathrm{p}$-value & Statistic & $\mathrm{p}$-value \\
\hline LLC -intercept & -12.3363 & $0.0000^{* *}$ & -10.3727 & $0.0000^{* *}$ \\
\hline LLC - intercept and trend & -10.7689 & $0.0000^{* *}$ & $-10,8571$ & $0.0000^{* *}$ \\
\hline LLC - none & -13.7604 & $0.0000^{* *}$ & -12.6464 & $0.0000^{* *}$ \\
\hline Breitung t-stat - intercept and trend & -5.71600 & $0.0000^{* *}$ & -5.49564 & $0.0000^{* *}$ \\
\hline IPS - intercept & -8.82654 & $0.0000^{* *}$ & $-7,16120$ & $0.0000^{* *}$ \\
\hline IPS - intercept and trend & -5.70319 & $0.0000^{* *}$ & -6.29651 & $0.0000^{* *}$ \\
\hline $\begin{array}{l}\text { Fisher ADF -intercept (Maddala i } \\
\text { Wu) }\end{array}$ & 123.500 & $0.0000^{* *}$ & 104.332 & $0.0000^{* *}$ \\
\hline $\begin{array}{l}\text { Fisher ADF - intercept and trend } \\
\text { (Maddala i Wu) }\end{array}$ & 81.8459 & $0.0000^{* *}$ & 90.3319 & $0.0000^{* *}$ \\
\hline Fisher ADF - none (Maddala i Wu) & 188.705 & $0.0000^{* *}$ & 176.161 & $0.0000^{* *}$ \\
\hline Fisher PP - intercept (Choi) & 137.446 & $0.0000^{* *}$ & 125.729 & $0.0000^{* *}$ \\
\hline $\begin{array}{l}\text { Fisher PP - intercept and trend } \\
\text { (Choi) }\end{array}$ & 98.8909 & $0.0000^{* *}$ & 153.517 & $0.0000^{* *}$ \\
\hline Fisher PP - none (Choi) & 187.077 & $0.0000^{* *}$ & 188.462 & $0.0000^{* *}$ \\
\hline Hadri - intercept & 0.74551 & 0.2280 & 1.84893 & $0.0322^{* *}$ \\
\hline \multicolumn{1}{|c|}{ Hadri - intercept and trend } & 7.13937 & $0.0000^{* *}$ & 5.34501 & $0.0000^{* *}$ \\
\hline
\end{tabular}

Source: Author's calculations

** Denotes significance at the level of $5 \%$ 
Results of panel unit root tests for data at the first difference of both the degree of openness of the economy and industrialization rates indicate that the hypothesis of the existence of a unit root can be rejected, on the basis of which it can be concluded that both variables are I(1) processes, meaning that they are integrated of the first order. Since the authors are trying to determine the existence of cointegration between, on the one hand, gross domestic product growth rate and the degree of openness of the economy, and on the other hand, gross domestic product growth rate and industrialization rate, a different level of integration of the variables does not allow the use of standard co-integration tests such as Pedroni, Kao and Fisher Johansen test. For this reason, when testing the co-integration between the variables the authors relied on the results of the relatively new panel ARDL (Auoregressive Distrubuted Lag) model proposed by Pesaran (1997) and Pesaran and Shin (1999). The model enables a consistent and effective estimation of both long- and short-term effects on the basis of panel data series that include a relatively large number of observation units and time instances, provided that the analyzed variables are of the same or different level of integration, but lower than I(2). The results of co-integration analysis based on ARDL model will be shown in continuation, by applying two methods of parameter estimation: Mean Group Estimator (MG) and Pooled Mean Group Estimator (PMG).

\subsection{ARDL model}

Paseran and Shin (1990) define the form of the dynamic ARDL (p, q) model as follows:

$$
y_{i t}=\sum_{j=1}^{p} \lambda_{i j} y_{i, t-j}+\sum_{j=0}^{q} \delta_{i j} x_{i, t-j}+\mu_{i}+\varepsilon_{i t}
$$

where:

- $i$ represents the number of observation units $i=1,2, \ldots, N$,

- $t$ represents the number of time instances $t=1,2, \ldots, T$,

- $x_{i t}$ is vector of independent variables of dimension $k \times 1$,

- $\lambda_{i j}$ is coefficient of lagged dependent variable,

- $\mu_{i}$ is parameter that determines the specific effects of the group or observation unit.

- The model from the expression (3.2) can be extended by including trend and other fixed regressors.

In the analysis the authors initially test whether a long-term co-integration relationship exists between the variables, and in the case prove that there is no cointegration the authors approach the analysis of short-term effects. Otherwise, if the authors prove that co-integration does exist between the variables, it will be necessary to form error correction model in order to determine the speed of short- 
term adjustment of the dependent variable to its long-term equilibrium. Error correction model is of the form:

$$
\Delta y_{i t}=\phi_{i}\left(y_{i, t-1}-\theta_{i} x_{i t}\right)+\sum_{j=1}^{p-1} \lambda_{i j}^{*} \Delta y_{i, t-1}+\sum_{j=0}^{q-1} \delta_{i j}^{*} \Delta x_{i, t-j}+\mu_{i}+\varepsilon_{i t}
$$

where $y_{i, t-1}-\theta_{i} x_{i t}$ represents error correction term, i.e. error correction coefficient that measures the speed of adjustment to long-term equilibrium.

The two most commonly used methods for parameter estimation of ADRL model are: Mean Group Estimator (MG) and Pooled Mean Group Estimator (PMG). These two parameter estimation methods were developed by Pesaran, Shin and Smith (1999), and their adventage is reflected in the fact that they are robust to heterogeneity of regression coefficients in structural dimension as well as to the existence of autocorrelation in time dimension.

Pooled Mean Group Estimator is characterized by the fact that it implies heterogeneity of coefficients which determine the existence of a long-term cointegration relationship between variables, while the coefficients of the speed of adjustment to long-term equilibrium, as well as the coefficients of the specific effects vary across observation units. Application of this method is justified and especially useful in situations when there are reasons to expect a similar long-term relation between the variables across all observation units, or at least among some of them. PMG Estimator will give consistent and efficient estimates, provided that certain conditions are met. The first condition, which is also necessary for making a decision on the existence of long-term relation between the variables, refers to the value of error correction coefficient. The value of this coefficient must be negative, but not less than -2 , and also statistically significant. The second condition for the fulfillment of the consistency of the results of ARDL model refers to non-existence of serial correlation between residuals of error correction model.

The second estimation method is Mean Group (MG) estimator based on the estimates of regression model for each observation unit individually. In other words it means that there are no restrictions in terms of coefficient homogeneity, meaning that the coefficients that determine both long- and short-term relationship between the variables may differ across observation units. In order for this method to provide consistent estimates, the number of observation units should vary between 20 and 30 , and each observation unit should have a sufficiently long time series of data.

In continuation, the authors will form two ARDL models that will evaluate the existence of co-integration relationship between, on the one hand, gross domestic product growth rate and the degree of openness of the economy, and on the other hand, gross domestic product growth rate and the level of country industrialization. For both models the authors will estimate the parameters using the PMG and the MG estimators, and then depending on the results of Hausman's test the authors will determine which of the two estimators provides better results. 
The results of the estimated dynamic ARDL models, with fixing the number of lags of both dependent and independent variables to 2, are presented in Tables 3.3. and 3.4 .

Table 3.3. Estimated ARDL model using the PMG and the MG method for evaluation of the existence of co-integration relationship between gross domestic product growth rate and the degree of openness of the economy

\begin{tabular}{|c|c|c|c|c|c|c|}
\hline D(GDPgrowth) & \multicolumn{3}{|c|}{ Pooled Mean Group (PMG) } & \multicolumn{3}{|c|}{ Mean Group (MG) } \\
\hline Variable & Coeff. & Std. Error & Prob.* & Coeff. & Std. Error & $\begin{array}{c}\text { Prob. } \\
*\end{array}$ \\
\hline $\begin{array}{l}\text { Long-term Coeff. } \\
\text { TGDP }\end{array}$ & -0.407641 & 0.0275381 & 0.141 & -4.821132 & 5.007439 & 0.336 \\
\hline $\begin{array}{l}\text { Error correction } \\
\text { Coeff. }\end{array}$ & $\overline{0.423111 * * *}$ & 0.0891625 & 0.000 & $\overline{0.5405834 * * *}$ & 0.149452 & 0.000 \\
\hline $\mathrm{D}$ (GDPgrowth(-1)) & -0.0793164 & 0.064121 & 0.218 & -0.0244718 & $\begin{array}{l}0.073656 \\
8\end{array}$ & 0.740 \\
\hline D(TGDP) & $\begin{array}{l}0.2741136^{* *} \\
*\end{array}$ & 0.045842 & 0.000 & $0.2370028 * * *$ & $\begin{array}{l}0.070282 \\
4\end{array}$ & 0.001 \\
\hline $\mathrm{D}(\mathrm{TGDP}(-1))$ & -0.0034526 & 0.0097315 & 0.922 & -0.035165 & $\begin{array}{l}0.041141 \\
4\end{array}$ & 0.393 \\
\hline Const. & $\begin{array}{l}0.0301148^{* *} \\
*\end{array}$ & 0.0097315 & 0.002 & -0.0225142 & $\begin{array}{l}0.028226 \\
9\end{array}$ & 0.425 \\
\hline \multirow{2}{*}{ Hausman test } & h-test & p-value & & & & \\
\hline & 0.76 & 0.3828 & & & & \\
\hline
\end{tabular}

Source: Author's calculations

*** Denotes significance at the level of $1 \%$

Table 3.4. Estimated ARDL model using the PMG and the MG method for evaluation of the existence of co-integration relationship between gross domestic product growth rate and industrialization rate

\begin{tabular}{|c|c|c|c|c|c|c|}
\hline D(GDPgrowth) & \multicolumn{3}{|c|}{ Pooled Mean Group (PMG) } & \multicolumn{3}{|c|}{ Mean Group (MG) } \\
\hline Variable & Coeff. & Std. Error & Prob.* & Coeff. & Std. Error & $\begin{array}{c}\text { Prob. } \\
*\end{array}$ \\
\hline $\begin{array}{l}\text { Long-term Coeff. } \\
\text { IND }\end{array}$ & $\begin{array}{l}0.4610112 * * \\
*\end{array}$ & 0.135027 & 0.001 & 0.7392687 & $\begin{array}{l}0.699946 \\
5\end{array}$ & 0.291 \\
\hline $\begin{array}{l}\text { Error correction } \\
\text { Coeff. }\end{array}$ & $0.746546^{* * *}$ & 0.1159246 & 0.000 & $\begin{array}{l} \\
0.9557118^{* * *}\end{array}$ & $\begin{array}{l}0.124309 \\
3 \\
\end{array}$ & 0.000 \\
\hline D(GDPgrowth(-1)) & -0.0078182 & 0.0912872 & 0.932 & 0.0756377 & $\begin{array}{l}0.097240 \\
8\end{array}$ & 0.437 \\
\hline $\mathrm{D}(\mathrm{IND})$ & $1.226611 * *$ & 0.5070382 & 0.016 & 0.8846888 & $\begin{array}{l}0.567055 \\
8\end{array}$ & 0.119 \\
\hline $\mathrm{D}(\mathrm{IND}(-1))$ & -0.0439517 & 0.4861542 & 0.928 & -0.234159 & $\begin{array}{l}0.461419 \\
4\end{array}$ & 0.612 \\
\hline Const. & $0.065862 * * *$ & 0.007046 & 0.000 & -0.2202399 & $\begin{array}{l}0.141278 \\
4 \\
\end{array}$ & 0.119 \\
\hline & h-test & p-value & & & & \\
\hline
\end{tabular}




\begin{tabular}{|l|l|l||}
\hline Hausman test & 0.11 & 0.7390 \\
\hline
\end{tabular}

Source: Author's calculations

*** Denotes significance at the level of $1 \%$

$* *$ Denotes significance at the level of $5 \%$

Considering that the Hausman test, for the models shown in Tables 3.3. and 3.4, indicated that in both cases the results of the PMG estimator are more efficient compared to the results of the MG estimator, therefore, the conclusions about the existence of co-integration relationship between the variables will be based on the results of the PMG estimator method.

It should be noted that the residuals of the estimated models fulfill the condition of normal distribution as well as the condition of the absence of serial correlation, thus achieving efficiency and consistency of the estimated models. Testing of normal distribution was carried out using Jarque-Berra, while for testing the absence of serial correlation between residuals of estimated models were used panel unit root tests of the first generation. Results of unit root tests for residuals of ARDL models (estimated by the PMG method and represented in Tables 3.3. and 3.4) have shown that series of the residuals for both models are stationary at the level. Values of unit root tests that indicate the absence of serial correlation between the residuals of estimated models are shown in Table 3.5.

Table 3.5. Results of unit root tests for the residuals of ARDL models

\begin{tabular}{|c|c|c|c|c|}
\hline & \multicolumn{2}{|c|}{$\begin{array}{l}\text { Residuals of ARDL } \\
\text { model } \\
\text { from Table } 3.3 .\end{array}$} & \multicolumn{2}{|c|}{$\begin{array}{c}\text { Residuals of ARDL } \\
\text { model } \\
\text { from Table 3.4. }\end{array}$} \\
\hline & Statistic & p-value & Statistic & p-value \\
\hline LLC -intercept & -10.8141 & $0.0000^{* * *}$ & -11.1633 & $0.0000^{* * *}$ \\
\hline LLC - intercept and trend & -9.22423 & $0.0000 * * *$ & -9.82913 & $0.0000^{* * *}$ \\
\hline LLC - none & -13.1389 & $0.0000^{* * *}$ & -13.6265 & $0.0000^{* * *}$ \\
\hline $\begin{array}{l}\text { Breitung t-stat - intercept and } \\
\text { trend }\end{array}$ & -1.66554 & $0.0479 * *$ & -5.68229 & $0.0000^{* * *}$ \\
\hline IPS - intercept & -7.49850 & $0.0000 * * *$ & -7.19122 & $0.0000^{* * *}$ \\
\hline IPS - intercept and trend & -4.26110 & $0.0000 * *$ & -4.89587 & $0.0000^{* * *}$ \\
\hline $\begin{array}{l}\text { Fisher ADF -intercept (Maddala i } \\
\text { Wu) }\end{array}$ & 106.122 & $0.0000^{* * *}$ & 101.656 & $0.0000^{* * *}$ \\
\hline $\begin{array}{l}\text { Fisher ADF - intercept and trend } \\
\text { (Maddala i Wu) }\end{array}$ & 67.7845 & $0.0001 * * *$ & 74.0559 & $0.0000 * * *$ \\
\hline Fisher ADF - none (Maddala i Wu) & 175.522 & $0.0000^{* * *}$ & 184.759 & $0.0000^{* * *}$ \\
\hline Fisher PP - intercept (Choi) & 112.941 & $0.0000^{* * *}$ & 112.558 & $0.0000^{* * *}$ \\
\hline $\begin{array}{l}\text { Fisher PP - intercept and trend } \\
\text { (Choi) }\end{array}$ & 101.641 & $0.0000^{* * *}$ & 120.420 & $0.0000^{* * *}$ \\
\hline Fisher PP - none (Choi) & 193.332 & $0.0000 * * *$ & 194.373 & $0.0000 * * *$ \\
\hline Hadri - intercept & 1.25297 & 0.1051 & 1.93787 & $0.0263 * *$ \\
\hline Hadri - intercept and trend & 9.85292 & $0.0000 * * *$ & 10.6154 & $0.0000 * * *$ \\
\hline
\end{tabular}

Source: Author's calculations 
$* * *$ Denotes significance at the level of $1 \%$
$* *$ Denotes significance at the level of $5 \%$

Once it has been proved that the models provided effective and consistent estimates, the authors can make a conclusion about the existence of co-integration relationship between observed variables on the basis of the values of coefficients and their statistical significance.

One can see in Table 3.3 that coefficient indicating a long-term relation between the rate of openness and growth rate of gross domestic product is not statistically significant and therefore it cannot be concluded that co-integration relation between these two variables exists.

This confirms the first part of our hypothesis how the „benefits from trade liberalization ceases after certain level is reached". Concretely, the openness level of observed countries in 2014 ranged between 75\% (Albania) and 170\% (Estonia), but it cannot be observed that countries with higher coefficient of openness are, at the same time, those with higher rate of economic growth. Considering that the authors used panel data, difference in openness rate in observation period (2000-2014) is still bigger, but even this did not bring to tangible proofs that significantly higher level of openness positively affected the rate of economic growth. Of course, this does not mean that openness is not useful at all. All arguments of endogenous theory of economic growth are valid. However, marginal benefits from the openness of the country when the openness already achieved a high level are low, while risks related to large openness are increasingly distinct.

More importantly, results of the ARDL model presented in Table 3.4 showed that coefficient of long-term relation between the industrialization rate and gross domestic product growth rate is positive and statistically significant, meaning that the growth rate of gross domestic products, observed in long-term period, depends on industrialization rate of the country. Admittedly, economic theory suggests us that this relation is positive only on the mid-level of income, which can be accepted.

Concretely, coefficient of long-term relation for the industrialization rate is 0.46 , which means if the industrialization rate is to be changed by $1 \%$, the growth rate of gross domestic product will increase by $0.46 \%$. This is important result. Although the growth rate acceleration of $0.46 \%$ does not seem important, as noticed by Piketty (2015), changes of growth rates within a long period of time, lead to huge differences in the development level of the country.

The fact that we determined and empirically proved relation between the level of industry share in GDP and GDP growth rate, gives a right to small transition countries to think about a need for reindustrialization. How to achieve it, that is absolutely different issue. 


\section{Conclusions}

Today, even IMF passes opinions of people who claim that reform of international financial and economic system is necessary in order to support development of insufficiently developed countries. However, as opposed to the IMF's counterparts who insist on more favorable loans, the authors think that fundamental reform is necessary, and not face-lifting. Concretely, results of our analysis show that the openness is award by itself only if the choice is between extreme solutions (autarchy and completely opened country). However, in conditions of highly liberal international trade it is clear that there are bigger and smaller winners from trade, while the latter could be considered as a relative losers. Therefore, favorable loans approved by IMF and WB to countries with continuous and expressed foreign trade imbalance, are not sufficient for current system of liberal trade to continue to function. The authors are of opinion that in accordance with "compensation principle" it is necessary to establish a system with non-return transfers from countries benefiting from free trade towards countries which are currently losers, in order to incite a growth of competitiveness in them. This is due to proved relation between (re)industrialization and faster economic development in countries with low to medium income per capita. WBG should, at least, introduce lines of non-return funds which would amount to certain percentage of trade surplus (e.g. 5\%) of developed countries realised in trade with undeveloped ones, for the purpose of financing the infrastructure necessary for undeveloped countries, and to be able to counter the developed countries in battle for new investments. Some steps in this field have already been made through IDU and EU Structural Funds, but, unfortunately they are insufficient. Although this seems as an extreme solution, the authors would like to remind of Keynes' proposals after the Great War (to enable trade surplus to Germany in order to pay debts), and at Breton Wood conference at the end of the World War II (to establish international monetary system within which the countries with trade surplus would also be responsible for maintenance of fixed foreign-exchange rates), which were not accepted by coevals, so a deep crisis occurred in international monetary, financial and trade systems.

This paper opened certain issues to which it did not provide a definitive answer due to limited scope. One of these questions is why trade liberalization does not provide positive results always and in the same extent. Our opinion is that the attention should be paid to economic and political institutions, or, to model of their functioning in small countries of East Europe. However, the authors did not go into depths of the problem in this field and it could be a topic for some other papers.

In addition, considering that population of developed countries would probably resist to financial transfers towards small countries of East Europe for the purpose of their reindustrialization, as feasible alternative there is a possibility to provide small developing countries with special trade treatment (again, as it is a case with the most undeveloped WTO members). Analysis of this compensation (asymmetric 
trade liberalization instead financial transfers for reindustrialization) could represent one additional interesting topic for detailed analysis.

At the end, the authors would like to emphasise that this paper should not be understand as interventionistic and especially as anti-globalization one. Free trade is a foundation of development, but if trade liberalization is performed under "adequate, not maximum rate", as Bhagwati would say. We hope that this paper provided some arguments to small countries of East Europe in their battle for faster development.

\section{References}

Acemoglu, R. and Robinson, J., 2012. Why Nations fail: The Origins of Power, Prosperity and Poverty, Crown Business, New York.https://doi.org/10.1355/ae29-2j

Asghar, N., Qureshi, S., Nadeem, M. 2015. "Institutional Quality and Economic Growth: Panel ARDL Analysis for Selected Developing Economies od Asia“, A Research Journal of South Asian Studies, Vol. 30, No.2, July-December, pp. 381-403.

Bhagwatti, J., 2004. In Defense of Globalization, OXFORD University Press, New York, https://doi.org/10.2307/40204318

Bhagwatti, J., 2005. In Defence of Globalization: It Has a Human Face, Angelo Costa Lecture, Rome.

Chang, H-J, 2016.Bad Samaritans: The guilty secrets of rich nations \& the treat toglobal prosperity; Mali Vrt, Belgrade.

Choi, I. 2001. "Unit root tests for panel data", Journal of International Money and Finance, vol. 20, issue 2, pp. 249-272, http://dx.doi.org/10.1016/S0261-5606(00)00048-6

Djogo, Marko., "Influence of financial liberation on countries in transation economies with review on Bosnia and Herzegovina.", master thesis, Faculty of Economics in East Sarajevo, University in East Sarajevo.

Erdem, E., Ucler, G., Bulut, U. 2014. "Impact of domestic credits on the current account balance: a panel ARDL analysis for 15 OECD countries", Journal "Actual Problems of Economics" No.1 (151),

Fukuyama, F., 1992.The End of History and the Last Man, New York, AVON BOOKS INC. https://doi.org/10.2307/20045133

Glavaški, O.,B. 2016. "Ekonometrijskomodeliranjeefikasnosti i održivostijavnepotrošnje u evropskimzemljama“, PhD Dissertation, Faculty of Economics, University of Belgrade

Gligorić, M.,Ž. 2015. “TranzicioneprivredeEvrope: konvergencija, izvoz i ukupna faktorska produktivnost", PhD Dissertation, Faculty of Economics, University of Belgrade

Harris, R.D., Tzavalis, E. 1999. "Inference for unit root in dynamic panels where the time dimension is fixed", Journal of Econometrics 91, pp. 201-226, http://dx.doi.org/10.1016/S0304-4076(98)00076-1

Im, K.S., Pesaran, M.H., Shin, Y. 2003. "Testing for unit roots in heterogeneous

panels“, Journal of Econometrics, vol. 115, pp. 53-74, http://dx.doi.org/10.1016/S03044076(03)00092-7

Kappler, M. 2006. "Panel Tests for Unit Roots in Hours Worked", Center for European Economic Research, Discussion Paper No. 06-022

Krugman, P., 1993. "The Narrow and Broad Arguments for Free Trade". The American Economic Review..http://www.jstor.org/stable/2117691 
Krugman, P. and Obstfels, M., (2009), International Economics-Theory and Policy(8 ${ }^{\text {th }}$ Edition), DATASTATUS, Belgrade.

Kwiatkowiski, D., Phillips, P., Schmidt, P., Shin, Y. 1992. "Testing the null hypothesis of stationarity against the alternative of a unit root: How sure are we that economic time series have a unit root?", Journal of Econometrics, vol.54, issue 1-3, pp. 159-178, http://dx.doi.org/10.1016/0304-4076(92)90104-Y

Levin, A., Lin, C.F., Chu, C.F.,J. 2002. "Unit root tests in panel data: asymptotic and finitesample properties", Journal of Econometrics 108, pp. 1-24, http://dx.doi.org/10.1016/S0304-4076(01)00098-7

Lojpur, A., 2016. Industrialization In Response To Question - Is Recovery of Countries In Transition Possible and How, in: Fifth International ConferenceJahorina Business Forum 2016 on 'Tourism and Competitiveness', Proceedings, Faculty of Economics in East Sarajevo, Jahorina, 24-26. February, pp. 25-36.

Lucas, R., 1988. "On the Mechanics of Economic Development".Journal of Monetary Economics.22(1): 3-42.doi:10.1016/0304-3932(88)90168-7

Maddala, G.,S., Wu, S. 1999. “A Comparative Study of Unit Root Tests with Panel Data and a New Simple Test", Oxford Bulletin of Economics and Staistics, vol. 61, issue S1, pp. 631-652, http://dx.doi.org/10.1111/1468-0084.61.s1.13

Milanovic, B., 2016. Global inequality-new approach for the age of globalization, Harvard, Harvard University Press.https://doi.org/10.4159/9780674969797

Miroudot, S., Lanz, R. and Ragoussis, A. 2009, Trade in Internmediate Goods and Services, $\begin{array}{llll}\text { OECD Working Papers No. 93, November } 2009 . & \text {. }\end{array}$ https://doi.org/10.1787/5kmlcxtdlk8r-en

Pandurevic, Nenad, "Free Trade and Foreign Policy in Function of Economic Development and European Integration of Bosnia and Herzegovina“, $\mathrm{PhD}$ dis. Faculty of Economics in East Sarajevo, University in East Sarajevo.

Pesaran, M.H., Shin, Y., 1999. “An Autoregressive Distributed Lag Modelling Approach to Cointegration Analysis“, Econometric and Economic Theory in the 20th Century: The RagnarFrish Centennial Symposium, 371-413, http://dx.doi.org/10.1017/CCOL0521633230.011

Piketty, T., 2015.Capital in 21st century, Buybook, Sarajevo. https://doi.org/10.4159/9780674369542

Ricupero, Rubens., Ismail, Faizel. andSiphana, Sok., 2005. "Why Shouled Small Developing Countries Engaged in the Global Trading System“, IMF Finance \& Development 1013.

Romer, P. M. 1994."The Origins of Endogenous Growth".The Journal of EconomicPerspectives.8(1).https://doi.org/10.1257/jep.8.1.3

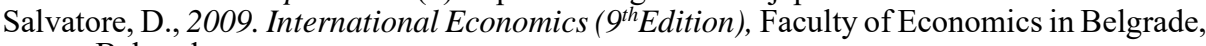
Belgrade.

Samargandi, N., Fidrmuc, J., Ghosh, S. 2013. "Is the Relationship between Financial Development and Economic Growth Monotonic for Middle Income Countries?", Brunel University London, Working paper No. 13-21, http://dx.doi.org/10.1016/j.worlddev.2014.11.010

Stiglitz, J., 2015. Rewriting the rules of American Economy: An agenda for growthand shared prosperity, New York, Random House Audio.

Stiglitz, J., 2002. Globalization and Its Discontents, W.W. Norton and Company Inc, New York. 
Stojanov, Dragoljub., 2012. "Dark Age of macroeconomics: The case study of transition in Bosnia and Herzegovina",

http://euroacademia.eu/wordpress/wp-content/uploads/2012/05/Dragoljub_Stojanov

_Dark_Age_Of_Economics_of_Transition_The_Case_of_BosniaHerzegovina\%E2\% 80\%99s_Economic_Transition.pdf

Vietor, R., 2010. How Countries Compete: Stratey, Structure, and Government in theGlobal Economy, MATE Zagreb, Zagreb.https://doi.org/10.5860/choice.44-6354

Vuic, J., 2010. The Yugo: The Rise and Fall of the Worse Car in History, Hill and Wang, a division of Farrar, Straus and Giroux, New York. https://doi.org/10.1353/tech.2011.0157

\section{POŽELJNI PRAVCI REFORME MEĐUNARODNOG TRGOVINSKOG SISTEMA IZ UGLA RAZVOJNIH POTREBA MALIH ZEMALJA ISTOČNE EVROPE}

Apstrakt: Otvorena ekonomija i reindustrijalizacija. Mogu li ove dvije pojave da egzistiraju istovremeno? Empirijska iskustva iz zemalja Istočne Evrope nam sugerišu da tako nešto nije moguće. Trgovinska liberalizacija u zemljama $u$ tranziciji sprovedena tokom 1990-ih je dovela do procesa deindustrijalizacije koji se nastavio tokom 2000-ih. Cilj ovoga rada je da predstavi mogući pravac reforme međunarodnog trgovinskog sistema koji bi omogućio reindustrijalizaciju malih zemalja Istočne Evrope, dok bi istovremeno očuvao dostignuti nivo trgovinske liberalizacije. Međutim, ono što nas deli od svi-su-na-dobitku situacije je uverenje da je ovo moguće samo pod uslovom da se primeni „kompenzatorni princip“ na međunarodnu trgovinu, prema kojem dobitnici iz međunarodne trgovine (razvijene zemlje koje ostvaruju trgovinski suficit) trebaju da „kompenzuju“ gubitnicima (malim zemljama u razvoju) deo njihovog gubitka kroz obavezujuce programe podrške reindustrijalizaciji zasnovanoj na izvozu, za šta sredstava hronično nedostaje. Alternativa je reindustrijalizacija bazirana na supstituciji uvoza tj. jačanje trgovinkskog protekcionozma, gdje bi sve prednosti slobodne trgovine nestale i na kraju bi svi bili na gubitku.

Ključne reči: trgovinske barijere, dobitci od trgovine, male zemlje

\section{Authors' biographies}

Marko Djogo was born in Sarajevo on 30 November 1983. He started his academic studies at the Faculty of Economics in East Sarajevo and completed it in 2006 as the student of generation. Since February 2007 he is employed at the Faculty of Economics. His fields of interest include International economy and finance, monetary economy, macroeconomic competitiveness etc. Since 2012 he became the chief of Department for banking in the Association of economists of the Republic of Srpska - SWOT. From November 2013 to October 2014, he was an advisor for economic issues to the Chairman of Parliamentary Assembly of Bosnia and Herzegovina, House of People. From October 2016, to July 2017, he attended post-doc studies at Faculty of Economics in Split, thanks to ERASMUS MUNDUS-Sunbeam scholarship. Now he is Acting Dean of Faculty of Economics in East Sarajevo, University in East Sarajevo. 
Vesna Prorok was born in 1985 in Sarajevo, where she attended elementary and high school. She graduated in 2007 at the Faculty of Economics of the University of East Sarajevo, Department of Finance, with 9.29 GPA. She received her master degree at the Faculty of Economics in East Sarajevo in May 2012. She won the best master-ofarts at the Faculty of Economics in East Sarajevo with 10.00 GPA. She was a student demonstrator at the course of General Mathematics. In June 2008, she was elected to the position of assistant at the Faculty of Economics in East Sarajevo, for the specific scientific field of Actuary, and as of September 2012 she was elected the senior assistant. From September 2012 to March 2013 she paid a study visit to the Faculty of Economics of the University of Bologna (study line of Quantitative Finance). She speaks English, Spanish and Italian language. 